NISTIR 6989

\title{
Comparison of ISO/IEC 17025 with the NUPIC Audit Checklist
}

\author{
C. Douglas Faison \\ Nationa Voluntary Laboratory Accreditation Program \\ Standard Services Division \\ Technology Services
}

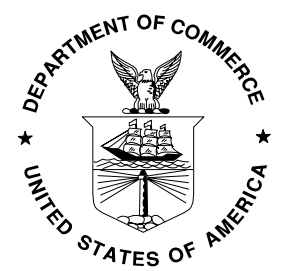

U.S. DEPARTMENT OF COMMERCE

Donald L. Evans, Secretary TECHNOLOGY ADMINISTRATION

Phillip J. Bond, Under Secretary of Commerce for Technology NATIONAL INSTITUTE OF STANDARDS AND TECHNOLOGY Arden L. Bement, Jr., Director 


\section{ACKNOWLEDGMENTS}

The author wishes to thank Clinton Eldridge, of the Pacific Gas \& Electric Company, for his input and guidance during the development of this comparison.

The author also wishes to thank Jeffrey Horlick, of NVLAP, for his critical review. His comments added clarity to the document making it much easier to read. 


\section{Table of Contents}

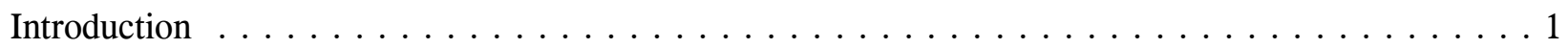

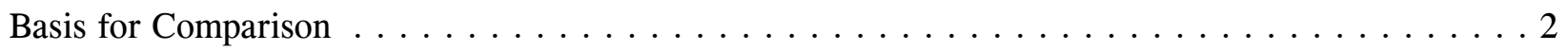

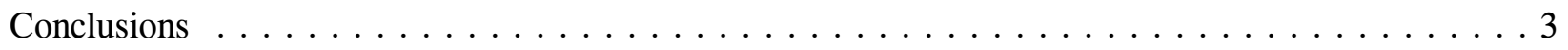

The Comparison

Section I - Training/Qualifications $\ldots \ldots \ldots \ldots \ldots \ldots \ldots \ldots \ldots \ldots \ldots \ldots \ldots \ldots \ldots \ldots \ldots$

Section II - Calibration System Description $\ldots \ldots \ldots \ldots \ldots \ldots \ldots \ldots \ldots \ldots \ldots \ldots \ldots$

Section III - Contract Requirements $\ldots \ldots \ldots \ldots \ldots \ldots \ldots \ldots \ldots$

Section IV - Adequacy of Measurement Standards $\ldots \ldots \ldots \ldots \ldots \ldots$

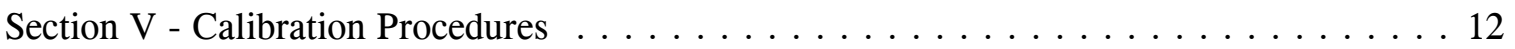

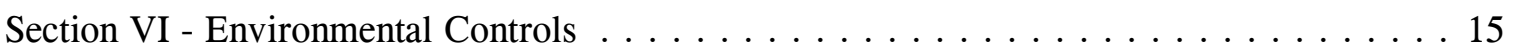

Section VII - Intervals of Calibration $\ldots \ldots \ldots \ldots \ldots \ldots \ldots \ldots \ldots \ldots \ldots \ldots \ldots \ldots \ldots$

Section VIII - Calibration Status $\ldots \ldots \ldots \ldots \ldots \ldots \ldots \ldots \ldots \ldots \ldots \ldots \ldots \ldots \ldots \ldots$

Section IX - Calibration Traceability $\ldots \ldots \ldots \ldots \ldots \ldots \ldots \ldots \ldots \ldots \ldots$

Section X-Subcontractor Calibration $\ldots \ldots \ldots \ldots \ldots \ldots$

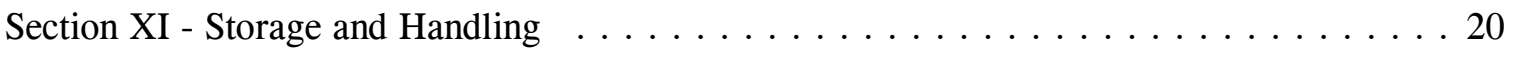

Section XII - Out of Tolerance/Corrective Action . . . . . . . . . . . . . 21

Section XIII - Calibration System Adequacy . . . . . . . . . . . . . . . . 24

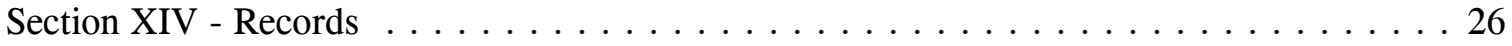

Appendix A, ISO/IEC 17025 Table of Contents $\ldots \ldots \ldots \ldots \ldots \ldots \ldots \ldots \ldots \ldots$ 
(blank page) 


\section{Introduction}

A meeting was held on August 5, 2002, in San Diego, Ca, during the National Conference of Standards Laboratories International (NCSLI) Conference and Symposium, to discuss Nuclear Regulatory Commission (NRC) recognition of the use of accredited commercial calibration laboratories as suppliers of commercial grade calibration services to regulated utilities. In attendance were:

Name

Dick Pettit

Clint Eldridge

Larry Nielsen

Jack Ferris

John Ragsdale

Roxanne Robinson

Tony Anderson

Mary Saunders

\section{Affiliation}

Sandia National Laboratories

Pacific Gas \& Electric

Southern California Edison

Sleeping Bear Metrology

Tennessee Valley Authority (TVA)

American Association for Laboratory Accreditation (A2LA)

(National Cooperation for Laboratory Accreditation (NACLA) President)

Guildline Instruments (NACLA Board member)

National Institute of Standards and Technology (NIST)

(NIST representative to NACLA Board)

NIST/National Voluntary Laboratory Accreditation Program (NVLAP)

Doug Faison

The purpose of the meeting was to map out a strategy for approaching the NRC concerning the issue of calibration laboratory accreditation and the National Cooperation for Laboratory Accreditation

(NACLA). The intent is to gain NRC endorsement of laboratory accreditation based on internationally accepted standards as a means of qualifying calibration service providers as suppliers to nuclear power facilities.

One of the group's defined tasks was to develop a gap analysis between the internationally accepted requirements for laboratory accreditation and NRC requirements. Copies of several NRC documents were obtained and, after a review of those documents, and on the advice of industry experts, it was decided that the comparison should be conducted using the audit requirements of the Nuclear Utilities Procurement Issues Committee (NUPIC), which most accurately reflect the requirements of 10CFR50, Appendix B, Quality Assurance Criteria for Nuclear Power Plants and Fuel Reprocessing Plants.

This document is, therefore, a comparison of NRC requirements, as defined by the NUPIC Commercial Grade Survey Checklist for Calibration Services, with the internationally accepted requirements for laboratory accreditation, contained in ISO/IEC 17025:1999, General requirements for the competence of testing and calibration laboratories. This document does not specifically discuss the process of laboratory accreditation and/or the process of peer evaluations of laboratory accreditation bodies for the purpose of mutual recognition. The left column gives the verbatim text from the NUPIC Checklist, the center column is the relevant text from 17025, and the right column provides commentary on the comparison between the two. 


\section{Basis for the Comparison}

The NUPIC Checklist is a set of 18 Methods of Verification spread over fourteen Sections of the checklist as follows:

Section I - Training/Qualifications

Section II - Calibration System Description

Section III - Contract Requirements

Section IV - Adequacy of Measurement Standards

Section V - Calibration Procedures

Section VI - Environmental Controls

Section VII - Intervals of Calibration
Section VIII - Calibration Status

Section IX - Calibration Traceability

Section X - Subcontractor Calibration

Section XI - Storage and Handling

Section XII - Out of Tolerance/Corrective Action

Section XIII - Calibration System Adequacy

Section XIV - Records

The language of the Methods of Verification appears to be taken from, or is at least very similar to, the requirements of ANSI/NCSL Z540-1-1994, the American National Standard for Calibration Calibration Laboratories and Measuring and Test Equipment - General Requirements. For each of the 18 Methods of Verification, there is reference to the relevant Z540 requirements section or clause(s).

For comparison purposes, only sections 4 and 5 of 17025 are relevant since Sections 1 through 3 contain the Scope of the Standard, References, and Definitions, but no requirements. However, clauses 1.1 and 1.2 of the Scope provide useful guidance as to the applicability of the standard as follows:

17025 clause $1.1 \quad$ "This International Standard specifies the general requirements for the competence to carry out tests and/or calibrations, including sampling. It covers testing and calibration performed using standard methods, non-standard methods, and laboratory-developed methods."

17025 clause $1.2 \quad$ "This International Standard is applicable to all organizations performing tests and/or calibrations. These include, for example, first-, second- and third-party laboratories, and laboratories where testing and/or calibration forms part of inspection and product certification."

Based on the way the NUPIC Methods of Verification are expressed, it is difficult in some cases to determine what would be considered as acceptable compliance. Without further guidance, compliance may be subject to the interpretation of the requirements by individual auditors. As can be seen in the comparison, ISO/IEC 17025, as implemented through the process of laboratory accreditation, is very specific concerning compliance to the standard.

As previously stated, the focus of this effort is on gaining NRC acceptance of accredited laboratories as suppliers of commercial grade calibration services only. Thus, the requirements of 10CFR21; Nuclear Regulatory Commission, Reporting of Defects and Noncompliance, are not relevant to this comparison.

\section{Conclusions}


In the final analysis, the comparison shows that 17025 adequately addresses all but two administrative issues, namely:

1. NUPIC clause 14.1.c.7 "The calibration certificate/report shall include identification of the laboratory equipment/standards used." 17025 does not require this, but does require that records be kept.

2. NUPIC clause 14.1.c.12 "The calibration certificate/report shall include as-found and as-left data." 17025 only requires as-found data to be reported when the device under test is adjusted/repaired.

One additional issue requires explanation. Clause 4.1 of the NUPIC checklist states, in part, "Well defined and documented measurement assurance techniques or uncertainty analyses may be used to verify the adequacy of the measurement process. If such techniques are not used, the collective uncertainty of the measurement standards shall not exceed $25 \%$ of the acceptable tolerance for each characteristic being calibrated." This is typically referred to as the four-to-one ratio. The NUPIC Checklist does not specifically require the four-to-one ratio but does allow its use if an uncertainty analysis is not available. 17025 requires an uncertainty analysis to support all measurement results, therefore the four-to-one ratio rule is not applicable.

However, clause 12.6 of Standard Review Plan (SRP) Section 17.1, Quality Assurance During the Design and Construction Phases Review Responsibilities, states "Calibration of this equipment should be against standards that have an accuracy of at least four times the required accuracy of the equipment being calibrated or, when this is not possible, have an accuracy that assures the equipment being calibrated will be within required tolerance and that the basis of acceptance is documented and authorized by responsible management. The management authorized to perform this function is identified." Although the SRP is not a requirements document and uses the term "should" instead of "shall", the four-to-one ratio has become something of a default requirement and industry experts believe this issue should be considered in this comparison.

Each of the three issues noted above can easily be addressed by requiring the utilities to add language to their purchase orders for commercial grade calibration services. For example, to address the four-toone ratio, the following requirement could be added. "the collective expanded uncertainty of the measurement standards must not exceed $25 \%$ of the acceptable tolerance for each characteristic being calibrated." Adding this statement to the purchase order would ensure that an uncertainty statement be provided, as required by 17025, and that the four-to-one ratio required by SRP 17.1 be maintained or exceeded. Similar statements could be added to the purchase order to require that standards used in the calibration process and all as-found and as-left data be reported in the Calibration Certificate/Report.

It should also be noted that 17025 contains many requirements, both management and technical, that are not addressed by the NUPIC checklist and are not included in the comparison. Laboratories accredited to 17025 have more thoroughly addressed those issues necessary to assure competence, capability, and traceability of measurement results. 
(blank page) 
Comparison of the NUPIC Commercial Grade Survey Checklist for Calibration Services

with ISO/IEC 17025: General requirements for the competence of testing and calibration laboratories.

\begin{tabular}{|c|c|c|}
\hline From the NUPIC Checklist & Relevant requirement(s) of ISO/IEC 17025 & Comments \\
\hline $\begin{array}{l}\text { Section I - Training/Qualifications } \\
1.1 \text { Verify personnel have sufficient } \\
\text { education, training, technical } \\
\text { knowledge, and experience for their } \\
\text { assigned functions. }\end{array}$ & $\begin{array}{l}\text { 5.2.1 The laboratory management shall ensure the competence } \\
\text { of all who operate specific equipment, perform tests and/or } \\
\text { calibrations, evaluate results, and sign test reports and calibration } \\
\text { certificates. When using staff who are undergoing training, } \\
\text { appropriate supervision shall be provided. Personnel performing } \\
\text { specific tasks shall be qualified on the basis of appropriate } \\
\text { education, training, experience and/or demonstrated skills, as } \\
\text { required. } \\
\text { 5.2.3 The laboratory shall use personnel who are employed by, } \\
\text { or under contract to, the laboratory. Where contracted and } \\
\text { additional technical and key support personnel are used, the } \\
\text { laboratory shall ensure that such personnel are supervised and } \\
\text { competent and that they work in accordance with the laboratory's } \\
\text { quality system. } \\
\text { 5.2.5 The management shall authorize specific personnel to } \\
\text { perform particular types of sampling, test and/or calibration, to } \\
\text { issue test reports and calibration certificates, to give opinions and } \\
\text { interpretations and to operate particular types of equipment. The } \\
\text { laboratory shall maintain records of the relevant authorization(s), } \\
\text { competence, educational and professional qualifications, training, } \\
\text { skills and experience of all technical personnel, including } \\
\text { contracted personnel. This information shall be readily available } \\
\text { and shall include the date on which authorization and/or } \\
\text { competence is confirmed. }\end{array}$ & $\begin{array}{l}\text { Section } 5.2 \text { of } 17025 \text { is dedicated to assuring } \\
\text { that all personnel are trained and qualified to } \\
\text { perform their duties. } \\
17025 \text { identifies management's responsibility } \\
\text { to ensure competence of personnel and } \\
\text { oversight of trainees. } \\
17025 \text { requires that all personnel, including } \\
\text { those under contract, follow the documented } \\
\text { quality system. } \\
\text { 17025 requires that management assume the } \\
\text { responsibility for authorizing specific } \\
\text { individuals to perform specific tasks and that } \\
\text { appropriate records be kept. }\end{array}$ \\
\hline
\end{tabular}




\begin{tabular}{|c|c|c|}
\hline From the NUPIC Checklist & Relevant requirement(s) of ISO/IEC 17025 & Comments \\
\hline $\begin{array}{l}\text { (continued) } \\
\text { Assess continuing training of } \\
\text { calibration personnel. }\end{array}$ & $\begin{array}{l}\text { 5.2.2 The management of the laboratory shall formulate the } \\
\text { goals with respect to the education, training and skills of the } \\
\text { laboratory personnel. The laboratory shall have a policy and } \\
\text { procedures for identifying training needs and providing training } \\
\text { of personnel. The training program shall be relevant to the } \\
\text { present and anticipated tasks of the laboratory. }\end{array}$ & $\begin{array}{l}17025 \text { specifically requires the lab to have } \\
\text { policies and procedures for identifying } \\
\text { training needs and that management be } \\
\text { responsible. }\end{array}$ \\
\hline $\begin{array}{l}\text { Section II - Calibration System } \\
\text { Description } \\
2.1 \text { Verify that the supplier has } \\
\text { established and documented a quality } \\
\text { system appropriate to the type, range } \\
\text { and volume of calibration activities } \\
\text { performed. }\end{array}$ & $\begin{array}{l}\text { 4.2.1 The laboratory shall establish, implement and maintain a } \\
\text { quality system appropriate to the scope of its activities. The } \\
\text { laboratory shall document its policies, systems, programs, } \\
\text { procedures and instructions to the extent necessary to assure the } \\
\text { quality of the test and/or calibration results. }\end{array}$ & $\begin{array}{l}17025 \text { specifies in detail the requirements for } \\
\text { a documented quality system. The entire } \\
\text { Section } 4 \text { Management Requirements is } \\
\text { relevant. }\end{array}$ \\
\hline $\begin{array}{l}\text { a. Are the calibration supplier's } \\
\text { policies and objectives defined? }\end{array}$ & $\begin{array}{l}\text { 4.2.2 The laboratory's quality system policies and objectives } \\
\text { shall be defined in a quality manual (however named). The } \\
\text { overall objectives shall be documented in a quality policy } \\
\text { statement. The quality policy statement shall be issued under the } \\
\text { authority of the chief executive. It shall include at least the } \\
\text { following: } \\
\text { a) the laboratory management's commitment to good } \\
\text { professional practice and to the quality of its testing and } \\
\text { calibration in servicing its clients; } \\
\text { the management's statement of the laboratory's standard } \\
\text { of service; } \\
\text { the objectives of the quality system; } \\
\text { a requirement that all personnel concerned with testing } \\
\text { and calibration activities within the laboratory } \\
\text { familiarize themselves with the quality documentation } \\
\text { d) and implement the policies and procedures in their } \\
\text { work; and } \\
\text { the laboratory management's commitment to compliance } \\
\text { with this International Standard. }\end{array}$ & $\begin{array}{l}17025 \text {, section } 4.2 \text { Quality System, requires } \\
\text { that policies and objectives be defined, that } \\
\text { they be documented in a quality policy } \\
\text { statement, and details what is to be included in } \\
\text { the policy statement. }\end{array}$ \\
\hline
\end{tabular}




\begin{tabular}{|c|c|c|}
\hline From the NUPIC Checklist & Relevant requirement(s) of ISO/IEC 17025 & Comments \\
\hline $\begin{array}{l}\text { b. Is the quality documentation } \\
\text { available for use by calibration } \\
\text { personnel? }\end{array}$ & $\begin{array}{l}4.2 .1 \ldots . \text { The system's documentation shall be communicated to, } \\
\text { understood by, available to, and implemented by the appropriate } \\
\text { personnel. }\end{array}$ & $\begin{array}{l}17025 \text { requires that the quality documentation } \\
\text { not only be available for use, but also that it } \\
\text { be communicated to and understood by } \\
\text { appropriate personnel. }\end{array}$ \\
\hline $\begin{array}{l}\text { c. Is there an organization chart } \\
\text { available? }\end{array}$ & $\begin{array}{l}\text { 4.1.5 The laboratory shall } \\
\text { e) define the organization and management structure of the } \\
\text { laboratory, its place in any parent organization, and the } \\
\text { relationships between quality management, technical } \\
\text { operations and support services; } \\
\text { specify the responsibility, authority and } \\
\text { interrelationships of all personnel who manage, perform } \\
\text { or verify work affecting the quality of the tests and/or } \\
\text { calibrations; } \\
\text { 4.2.4 The roles and responsibilities of technical management } \\
\text { and the quality manager, including their responsibility for } \\
\text { ensuring compliance with this standard, shall be defined in the } \\
\text { quality manual. }\end{array}$ & $\begin{array}{l}17025 \text { requires that the organization be well } \\
\text { defined and that interrelationships of all } \\
\text { personnel also be specified. }\end{array}$ \\
\hline $\begin{array}{l}\text { d. Does the quality system document } \\
\text { provide for: scope of lab activities, } \\
\text { personnel training, procedure control, } \\
\text { maintenance of standards, } \\
\text { identification and control of } \\
\text { discrepancies, internal audits, and } \\
\text { reports/records. }\end{array}$ & $\begin{array}{l}\text { 4.2.3 The quality manual shall include or make reference to the } \\
\text { supporting procedures including technical procedures. It shall } \\
\text { outline the structure of the documentation used in the quality } \\
\text { system. }\end{array}$ & $\begin{array}{l}\text { This requirement appears to have been drawn } \\
\text { from Z540-1, section } 5.2 \text {, which states that } \\
\text { the quality manual and related documentation } \\
\text { shall also include... This requirement was } \\
\text { deleted in } 17025 \text { because too many labs were } \\
\text { incorrectly developing QMs that addressed } \\
\text { only the listed elements. } 17025 \text {, section } 4.2 \\
\text { Quality System, requires that all elements of } \\
\text { the standard be addressed in the QM, } \\
\text { including those specified in the NUPIC } \\
\text { checklist. }\end{array}$ \\
\hline
\end{tabular}




\begin{tabular}{|c|c|c|}
\hline From the NUPIC Checklist & Relevant requirement(s) of ISO/IEC 17025 & Comments \\
\hline $\begin{array}{l}\text { e. Does quality system document } \\
\text { address 10CFR50 Appendix B and } \\
\text { 10CFR21? Does supplier accept } \\
\text { customer orders with 10CFR21 } \\
\text { invoked? (for information purposes } \\
\text { only) }\end{array}$ & $\begin{array}{l}\text { Not a specific requirement of } 17025 \text {. However, the relevant } \\
\text { clauses are: } \\
\text { 4.2.1 The laboratory shall establish, implement and maintain a } \\
\text { quality system appropriate to the scope of its activities. } \\
\text { 4.4.1 The laboratory shall establish and maintain procedures for } \\
\text { the review of requests, tenders and contracts. The policies and } \\
\text { procedures for these reviews leading to a contract for testing } \\
\text { and/or calibration shall ensure that: } \\
\text { a) the requirements, including the methods to be used, are } \\
\text { adequately defined, documented and understood (see } \\
5.4 .2 \text {; } \\
\text { the laboratory has the capability and resources to meet } \\
\text { the requirements; }\end{array}$ & $\begin{array}{l}\text { Only commercial grade calibration services } \\
\text { are being considered. Therefore, 10CFR } 21 \text { is } \\
\text { not applicable. } \\
\text { The NUPIC checklist is designed to address } \\
\text { the requirements of 10CFR } 50 \text { Appendix B. } \\
\text { Therefore, it is } 17025 \text { in its entirety that is } \\
\text { relevant. }\end{array}$ \\
\hline
\end{tabular}




\begin{tabular}{|c|c|c|}
\hline From the NUPIC Checklist & Relevant requirement(s) of ISO/IEC 17025 & Comments \\
\hline $\begin{array}{l}\text { Section III - Contract } \\
\text { Requirements } \\
3.1 \text { Verify that deviations/exceptions } \\
\text { to customer purchase orders are } \\
\text { documented and controlled: } \\
\text { a. Exceptions to purchase order } \\
\text { discussed/resolved at order entry, } \\
\text { prior to work }\end{array}$ & $\begin{array}{l}\text { 4.4.1 The laboratory shall establish and maintain procedures for } \\
\text { the review of requests, tenders and contracts. The policies and } \\
\text { procedures for these reviews leading to a contract for testing } \\
\text { and/or calibration shall ensure that: } \\
\text { a) } \\
\text { the requirements, including the methods to be used, are } \\
\text { adequately defined, documented and understood (see } \\
5.4 .2 \text { ); } \\
\text { the laboratory has the capability and resources to meet } \\
\text { the requirements; } \\
\text { the appropriate test and/or calibration method is selected } \\
\text { and capable of meeting the clients' requirements (see } \\
\text { 5.4.2). } \\
\text { c) Any differences between the request or tender and the contract } \\
\text { shall be resolved before any work commences. Each contract } \\
\text { shall be acceptable both to the laboratory and the client. } \\
4.4 .2 \text { Records of reviews, including any significant changes, } \\
\text { shall be maintained. Records shall also be maintained of pertinent } \\
\text { discussions with a client relating to the client's requirements or } \\
\text { the results of the work during the period of execution of the } \\
\text { contract. } \\
4.4 .3 \text { The review shall also cover any work that is subcontracted } \\
\text { by the laboratory. } \\
4.4 .4 \text { The client shall be informed of any deviation from the } \\
\text { contract. } \\
4.4 .5 \text { If a contract needs to be amended after work has } \\
\text { commenced, the same contract review process shall be repeated } \\
\text { and any amendments shall be communicated to all affected } \\
\text { personnel. }\end{array}$ & $\begin{array}{l}17025 \text { has added a complete section ( } 4.4) \text { that } \\
\text { deals with the review of requests, tenders and } \\
\text { contracts which specifies in detail the } \\
\text { necessary steps to be taken, records to be } \\
\text { kept, etc. }\end{array}$ \\
\hline
\end{tabular}




\begin{tabular}{|c|c|c|}
\hline From the NUPIC Checklist & Relevant requirement(s) of ISO/IEC 17025 & Comments \\
\hline $\begin{array}{l}\text { b. Damaged/defective equipment } \\
\text { noted at receipt } \\
\text { c. Out-of-tolerance condition of } \\
\text { customer equipment noted }\end{array}$ & $\begin{array}{l}\text { 5.8.3 Upon receipt of the test or calibration item, abnormalities } \\
\text { or departures from normal or specified conditions, as described } \\
\text { in the test or calibration method, shall be recorded. When there } \\
\text { is doubt as to the suitability of an item for test or calibration, or } \\
\text { when an item does not conform to the description provided, or } \\
\text { the test or calibration required is not specified in sufficient detail, } \\
\text { the laboratory shall consult the client for further instructions } \\
\text { before proceeding and shall record the discussion. }\end{array}$ & $\begin{array}{l}17025 \text { requirements for handling procedures } \\
\text { exceed those of the NUPIC checklist. }\end{array}$ \\
\hline $\begin{array}{l}\text { Section IV - Adequacy of } \\
\text { Measurement Standards } \\
4.1 \text { Verify the measurement } \\
\text { standards used by the supplier for } \\
\text { calibration of M\&TE and other } \\
\text { measurement standards have the } \\
\text { accuracy, stability, range, and } \\
\text { resolution required for the instrument } \\
\text { calibrated. }\end{array}$ & $\begin{array}{l}\text { 5.5.1 The laboratory shall be furnished with all items of } \\
\text { sampling, measurement and test equipment required for the } \\
\text { correct performance of the tests and/or calibrations (including } \\
\text { sampling, preparation of test and/or calibration items, processing } \\
\text { and analysis of test and/or calibration data). In those cases where } \\
\text { the laboratory needs to use equipment outside its permanent } \\
\text { control, it shall ensure that the requirements of this standard are } \\
\text { met. } \\
\text { 5.5.2 Equipment and its software used for testing, calibration } \\
\text { and sampling shall be capable of achieving the accuracy required } \\
\text { and shall comply with specifications relevant to the tests and/or } \\
\text { calibrations concerned. Calibration programs shall be established } \\
\text { for key quantities or values of the instruments where these } \\
\text { properties have a significant effect on the results. Before being } \\
\text { placed into service, equipment (including that used for sampling) } \\
\text { shall be calibrated or checked to establish that it meets the } \\
\text { laboratory's specification requirements and complies with the } \\
\text { relevant standard specifications. It shall be checked and/or } \\
\text { calibrated before use. }\end{array}$ & $\begin{array}{l}17025 \text { does not differentiate between } \\
\text { requirements for customer calibrations and } \\
\text { those done in support of those calibrations, } \\
\text { e.g., on in-house M\&TE. The ultimate goal } \\
\text { of } 17025 \text { is to ensure that all services provided } \\
\text { by the lab are appropriate and traceable. This } \\
\text { includes all calibrations done, either by the lab } \\
\text { or through calibration services provided to the } \\
\text { lab, in support of the calibration services } \\
\text { provided by the lab. Accredited laboratories } \\
\text { must be able to show evidence that their } \\
\text { measurements are scientifically sound and that } \\
\text { they are traceable to appropriate stated } \\
\text { references. This includes evidence on the } \\
\text { traceability of standards and test equipment } \\
\text { used in performance of the services provided. } \\
\text { Furthermore, uncertainty budgets for services } \\
\text { provided must include components attributable } \\
\text { to these standards, M\&TE and other ancillary } \\
\text { equipment to the extent they affect } \\
\text { measurement results. }\end{array}$ \\
\hline
\end{tabular}




\begin{tabular}{|c|c|c|}
\hline From the NUPIC Checklist & Relevant requirement(s) of ISO/IEC 17025 & Comments \\
\hline $\begin{array}{l}\text { The laboratory shall ensure that the } \\
\text { measurement uncertainties are } \\
\text { sufficiently small as (sic) that the } \\
\text { adequacy of the measurement is not } \\
\text { affected. }\end{array}$ & $\begin{array}{l}\text { 5.4.6.1 A calibration laboratory, or a testing laboratory } \\
\text { performing its own calibrations, shall have and shall apply a } \\
\text { procedure to estimate the uncertainty of measurement for all } \\
\text { calibrations and types of calibrations. } \\
\text { 5.10.4.2 When statements of compliance are made, the } \\
\text { uncertainty of measurement shall be taken into account. }\end{array}$ & $\begin{array}{l}\text { All parts of the required chain of traceability } \\
\text { for providing service appropriate to customer } \\
\text { needs. } 17025 \text { does not specifically address the } \\
\text { size of the uncertainty. Only the user can } \\
\text { determine the adequacy of the measurement. } \\
\text { Hence, the uncertainty is always provided. }\end{array}$ \\
\hline $\begin{array}{l}\text { Well defined and documented } \\
\text { measurement assurance techniques or } \\
\text { uncertainty analyses may be used to } \\
\text { verify the adequacy of the } \\
\text { measurement process. }\end{array}$ & $\begin{array}{l}\text { 5.4.6.3 When estimating the uncertainty of measurement, all } \\
\text { uncertainty components which are of importance in the given } \\
\text { situation shall be taken into account using appropriate methods of } \\
\text { analysis. }\end{array}$ & $\begin{array}{l}17025 \text { requires that uncertainties associated } \\
\text { with environmental factors, the measurement } \\
\text { of those factors, and other possible } \\
\text { contributions from measuring equipment be } \\
\text { considered. }\end{array}$ \\
\hline $\begin{array}{l}\text { If such techniques are not used, the } \\
\text { collective uncertainty of the } \\
\text { measurement standards shall not } \\
\text { exceed } 25 \% \text { of the acceptable } \\
\text { tolerance for each characteristic being } \\
\text { calibrated. }\end{array}$ & $\begin{array}{l}\text { 5.4.6.1 A calibration laboratory, or a testing laboratory } \\
\text { performing its own calibrations, shall have and shall apply a } \\
\text { procedure to estimate the uncertainty of measurement for all } \\
\text { calibrations and types of calibrations. } \\
\text { 5.4.6.3 When estimating the uncertainty of measurement, all } \\
\text { uncertainty components which are of importance in the given } \\
\text { situation shall be taken into account using appropriate methods of } \\
\text { analysis. }\end{array}$ & $\begin{array}{l}\text { The NUPIC statement makes an allowance if } \\
\text { well defined and documented measurement } \\
\text { assurance techniques or uncertainty analyses } \\
\text { are not available. In } 17025 \text {, all calibrations } \\
\text { must be supported by an appropriate } \\
\text { uncertainty analysis, there is no allowance for } \\
\text { the } 25 \% \text { rule. } \\
\text { It should be noted that the } 25 \% \text { rule does not } \\
\text { assure traceability of measurements and is not } \\
\text { an acceptable alternative to the need for a } \\
\text { thorough uncertainty analysis. The term } \\
\text { "uncertainty of the measurement standard" is } \\
\text { incorrect. Uncertainty, by definition, is } \\
\text { associated with the results of a measurement } \\
\text { or the value of a standard, not the standard } \\
\text { used in making the measurement. }\end{array}$ \\
\hline
\end{tabular}




\begin{tabular}{|c|c|c|}
\hline From the NUPIC Checklist & Relevant requirement(s) of ISO/IEC 17025 & Comments \\
\hline $\begin{array}{l}\text { Section } \mathbf{V} \text { - Calibration Procedures } \\
5.1 \text { Verify procedures are available } \\
\text { and are utilized for calibration of } \\
\text { M\&TE and standards and that they } \\
\text { specify: } \\
\text { Standard(s) to be used } \\
\text { Equipment to be used } \\
\text { The required parameter, range, and } \\
\text { accuracy of the standard }\end{array}$ & $\begin{array}{l}\text { 5.4.1 The laboratory shall use appropriate methods and } \\
\text { procedures for all tests and/or calibrations within its scope. } \\
\text { These include sampling, handling, transport, storage and } \\
\text { preparation of items to be tested and/or calibrated, and, where } \\
\text { appropriate, an estimation of the measurement uncertainty as } \\
\text { well as statistical techniques for analysis of test and/or calibration } \\
\text { data. } \\
5.4 .2 \text { The laboratory shall use test and/or calibration methods, } \\
\text { including methods for sampling, which meet the needs of the } \\
\text { client and which are appropriate for the tests and/or calibrations } \\
\text { it undertakes. } \\
\text { 5.5.2 Equipment and its software used for testing, calibration } \\
\text { and sampling shall be capable of achieving the accuracy required } \\
\text { and shall comply with specifications relevant to the tests and/or } \\
\text { calibrations concerned. Calibration programs shall be established } \\
\text { for key quantities or values of the instruments where these } \\
\text { properties have a significant effect on the results. Before being } \\
\text { placed into service, equipment (including that used for sampling) } \\
\text { shall be calibrated or checked to establish that it meets the } \\
\text { laboratory's specification requirements and complies with the } \\
\text { relevant standard specifications. It shall be checked and/or } \\
\text { calibrated before use. } \\
\text { 5.6.1 All equipment used for tests and/or calibrations, including } \\
\text { equipment for subsidiary measurements (e.g., for environmental } \\
\text { conditions) having a significant effect on the accuracy or validity } \\
\text { of the result of the test, calibration or sampling shall be } \\
\text { calibrated before being put into service. The laboratory shall } \\
\text { have an established program and procedure for the calibration of } \\
\text { its equipment. }\end{array}$ & $\begin{array}{l}\text { As previously discussed, } 17025 \text { requires that } \\
\text { all real or potential influences on the } \\
\text { uncertainty of measurement results be } \\
\text { addressed. }\end{array}$ \\
\hline
\end{tabular}




\begin{tabular}{|c|c|c|}
\hline From the NUPIC Checklist & Relevant requirement(s) of ISO/IEC 17025 & Comments \\
\hline $\begin{array}{l}5.2 \text { Verify that when a device } \\
\text { tolerance (range) is not known or } \\
\text { specified and an uncertainty } \\
\text { (regression) analysis is performed, } \\
\text { adequate procedure controls exist to } \\
\text { control sampling of data used for the } \\
\text { analysis. Assess the } \\
\text { rationale/justification for the } \\
\text { sampling plan selected. }\end{array}$ & $\begin{array}{l}\text { 5.4.1 The laboratory shall use appropriate methods and } \\
\text { procedures for all tests and/or calibrations within its scope. } \\
\text { These include sampling, handling, transport, storage and } \\
\text { preparation of items to be tested and/or calibrated, and, where } \\
\text { appropriate, an estimation of the measurement uncertainty as } \\
\text { well as statistical techniques for analysis of test and/or calibration } \\
\text { data. } \\
\text { 5.7.1 The laboratory shall have a sampling plan and procedures } \\
\text { for sampling when it carries out sampling of substances, } \\
\text { materials or products for subsequent testing or calibration. The } \\
\text { sampling plan as well as the sampling procedure shall be } \\
\text { available at the location where sampling is undertaken. Sampling } \\
\text { plans shall, whenever reasonable, be based on appropriate } \\
\text { statistical methods. The sampling process shall address the } \\
\text { factors to be controlled to ensure the validity of the test and } \\
\text { calibration results. } \\
\text { 5.7.3 The laboratory shall have procedures for recording } \\
\text { relevant data and operations relating to sampling that forms part } \\
\text { of the testing or calibration that is undertaken. These records } \\
\text { shall include the sampling procedure used, the identification of } \\
\text { the sampler, environmental conditions (if relevant) and diagrams } \\
\text { or other equivalent means to identify the sampling location as } \\
\text { necessary and, if appropriate, the statistics the sampling } \\
\text { procedures are based upon. }\end{array}$ & $\begin{array}{l}\text { This NUPIC requirement appears to be tied to } \\
\text { Z540-1, clause } 10.5 \text { which addresses when } \\
\text { sampling is carried out as part of the } \\
\text { calibration method, not when (and if) sample } \\
\text { data is used for the uncertainty analysis. In } \\
\text { reality, all data used for uncertainty analyses } \\
\text { are sample data. Also, an uncertainty of a } \\
\text { measurement result is required whether or not } \\
\text { the tolerance of the device under test is } \\
\text { known or specified. } \\
\text { The original requirement came from ISO/IEC } \\
\text { Guide } 25 \text {, which was the basis for Z540-1 and } \\
\text { was applicable to both calibration and testing } \\
\text { labs. Sampling is a concept employed mostly } \\
\text { by test labs where, for example, samples from } \\
\text { a batch are tested, but not the entire batch, or } \\
\text { where the test is destructive, so that only } \\
\text { selected samples are tested. The requirement } \\
\text { was left in Z540-1 for those few instances } \\
\text { where sampling may be applicable to } \\
\text { calibrations. One example is calibration of a } \\
\text { roll of thermocouple wire: the entire roll is } \\
\text { not tested, but usually three segments of wire } \\
\text { are tested: one from each end and one from } \\
\text { the middle. } \\
\text { The requirement is well covered by } 17025 \\
\text { should it be applicable to any calibrations } \\
\text { performed where sampling is part of the } \\
\text { method. }\end{array}$ \\
\hline
\end{tabular}




\begin{tabular}{|c|c|c|}
\hline From the NUPIC Checklist & Relevant requirement(s) of ISO/IEC 17025 & Comments \\
\hline $\begin{array}{l}5.3 \text { Verify calculations and data } \\
\text { transfers are subject to appropriate } \\
\text { checks. }\end{array}$ & $\begin{array}{l}\text { 5.4.7.1 Calculations and data transfers shall be subject to } \\
\text { appropriate checks in a systematic manner. }\end{array}$ & $\begin{array}{l}17025 \text { requires that checks be accomplished in } \\
\text { a systematic manner. }\end{array}$ \\
\hline $\begin{array}{l}5.4 \text { Verify when computers or } \\
\text { automated equipment are used for the } \\
\text { capture, processing, manipulation, } \\
\text { recording, reporting, storage, or } \\
\text { retrieval of calibration data, the } \\
\text { laboratory ensures that: }\end{array}$ & $\begin{array}{l}\text { 5.4.7.2 When computers or automated equipment are used for } \\
\text { the acquisition, processing, recording, reporting, storage or } \\
\text { retrieval of test or calibration data, the laboratory shall ensure } \\
\text { that: }\end{array}$ & $\begin{array}{l}17025 \text { requirements are more prescriptive and } \\
\text { are an improvement over Z540-1 and NUPIC } \\
\text { requirements. }\end{array}$ \\
\hline $\begin{array}{l}\text { a. Computer software is } \\
\text { documented and adequate } \\
\text { for use; }\end{array}$ & $\begin{array}{l}\text { a. computer software developed by the user is documented } \\
\text { in sufficient detail and is suitably validated as being } \\
\text { adequate for use; }\end{array}$ & \\
\hline $\begin{array}{l}\text { b. Procedures are established } \\
\text { and implemented for } \\
\text { protecting the integrity and } \\
\text { security of data; }\end{array}$ & $\begin{array}{l}\text { b. } \\
\text { procedures are established and implemented for } \\
\text { not be limited to, integrity and confidentiality of data } \\
\text { entry or collection, data storage, data transmission and } \\
\text { data processing; }\end{array}$ & \\
\hline $\begin{array}{l}\text { Computer and automated } \\
\text { equipment is maintained to } \\
\text { ensure proper functioning } \\
\text { and provided with the } \\
\text { environmental and operating } \\
\text { conditions necessary to } \\
\text { maintain the integrity of } \\
\text { calibration data. }\end{array}$ & $\begin{array}{l}\text { c. computers and automated equipment are maintained to } \\
\text { ensure proper functioning and are provided with the } \\
\text { environmental and operating conditions necessary to } \\
\text { maintain the integrity of test and calibration data. }\end{array}$ & \\
\hline
\end{tabular}




\begin{tabular}{|c|c|c|}
\hline From the NUPIC Checklist & Relevant requirement(s) of ISO/IEC 17025 & Comments \\
\hline $\begin{array}{l}\text { Section VI - Environmental } \\
\text { Controls } \\
6.1 \text { Verify M\&TE and standards are } \\
\text { calibrated and utilized in an } \\
\text { environment controlled to the extent } \\
\text { necessary to assure continued } \\
\text { measurements of required accuracy } \\
\text { (i.e., humidity, temperature, EMI, } \\
\text { line voltage, sound/vibration levels, } \\
\text { and cleanliness). }\end{array}$ & $\begin{array}{l}\text { 5.3.1 Laboratory facilities for testing and/or calibration, } \\
\text { including but not limited to energy sources, lighting and } \\
\text { environmental conditions, shall be such as to facilitate correct } \\
\text { performance of the tests and/or calibrations. } \\
\text { The laboratory shall ensure that the environmental conditions do } \\
\text { not invalidate the results or adversely affect the required quality } \\
\text { of any measurement. Particular care shall be taken when } \\
\text { sampling and tests and/or calibrations are undertaken at sites } \\
\text { other than a permanent laboratory facility. The technical } \\
\text { requirements for accommodation and environmental conditions } \\
\text { that can affect the results of tests and calibrations shall be } \\
\text { documented. } \\
\text { 5.3.2 The laboratory shall monitor, control and record } \\
\text { environmental conditions as required by the relevant } \\
\text { specifications, methods and procedures or where they influence } \\
\text { the quality of the results. Due attention shall be paid, for } \\
\text { example, to biological sterility, dust, electromagnetic } \\
\text { disturbances, radiation, humidity, electrical supply, temperature, } \\
\text { and sound and vibration levels, as appropriate to the technical } \\
\text { activities concerned. Tests and calibrations shall be stopped when } \\
\text { the environmental conditions jeopardize the results of the tests } \\
\text { and/or calibrations. } \\
\text { 5.3.3 There shall be effective separation between neighboring } \\
\text { areas in which there are incompatible activities. Measures shall } \\
\text { be taken to prevent cross-contamination. } \\
\text { 5.3.4 Access to and use of areas affecting the quality of the tests } \\
\text { and/or calibrations shall be controlled. The laboratory shall } \\
\text { determine the extent of control based on its particular } \\
\text { circumstances. } \\
5.3 .5 \text { Measures shall be taken to ensure good housekeeping in } \\
\text { the laboratory. Special procedures shall be prepared where } \\
\text { necessary. }\end{array}$ & $\begin{array}{l}17025 \text { specifically identifies requirements for } \\
\text { documentation of conditions that can affect } \\
\text { results and requires that the tests and } \\
\text { calibrations are to be stopped when } \\
\text { environmental conditions jeopardize the } \\
\text { results. } 17025 \text { also requires that any influence } \\
\text { on the results of measurements attributable to } \\
\text { environmental factors be accounted for in the } \\
\text { uncertainty analyses. }\end{array}$ \\
\hline
\end{tabular}




\begin{tabular}{|c|c|c|}
\hline From the NUPIC Checklist & Relevant requirement(s) of ISO/IEC 17025 & Comments \\
\hline $\begin{array}{l}\text { Section VII - Intervals of } \\
\text { Calibration } \\
7.1 \text { Verify the supplier has a recall } \\
\text { system established to assure M\&TE } \\
\text { and standards are calibrated at } \\
\text { established intervals and maintained } \\
\text { to assure acceptable accuracy and } \\
\text { reliability. }\end{array}$ & $\begin{array}{l}\text { 5.6.1 All equipment used for tests and/or calibrations, including } \\
\text { equipment for subsidiary measurements (e.g., for environmental } \\
\text { conditions) having a significant effect on the accuracy or validity } \\
\text { of the result of the test, calibration or sampling shall be } \\
\text { calibrated before being put into service. The laboratory shall } \\
\text { have an established program and procedure for the calibration of } \\
\text { its equipment. }\end{array}$ & $\begin{array}{l}\text { While } 17025 \text { does not use the term "recall," it } \\
\text { does require that the lab have an on-going } \\
\text { program and procedure for determining and } \\
\text { setting intervals in place. }\end{array}$ \\
\hline $\begin{array}{l}\text { Section VIII - Calibration Status } \\
8.1 \text { a. Verify M\&TE and standards } \\
\text { are uniquely identified and labeled to } \\
\text { indicate calibration status (minimum } \\
\text { calibration date and calibration due } \\
\text { date). Where impractical to label the } \\
\text { item, the vendor shall provide other } \\
\text { suitable means to identify the status } \\
\text { of them. } \\
\text { b. Items that are not calibrated to } \\
\text { their full range, or have other } \\
\text { limitations, shall be identified to that } \\
\text { condition. }\end{array}$ & $\begin{array}{l}\text { 5.5.8 Whenever practicable, all equipment under the control } \\
\text { of the laboratory and requiring calibration shall be labeled, coded } \\
\text { or otherwise identified to indicate the status of calibration, } \\
\text { including the date when last calibrated and the date or expiration } \\
\text { criteria when recalibration is due. }\end{array}$ & $\begin{array}{l}17025 \text { requires that all equipment be labeled } \\
\text { or otherwise identified so that its calibration } \\
\text { status and its fitness for purpose can be } \\
\text { determined. This includes identification of } \\
\text { limitations, etc. }\end{array}$ \\
\hline $\begin{array}{l}\text { c. Also verify that the supplier has } \\
\text { controls in place to apply tamper } \\
\text { resistant seals to operator accessible } \\
\text { controls or adjustments, which if } \\
\text { moved, would affect the calibration. } \\
\text { The calibration system shall provide } \\
\text { instructions for use of the seals and } \\
\text { disposition on items whose seals are } \\
\text { broken. }\end{array}$ & $\begin{array}{l}\text { 5.5.12 Test and calibration equipment, including both hardware } \\
\text { and software, shall be safeguarded from adjustments which } \\
\text { would invalidate the test and/or calibration results. }\end{array}$ & $\begin{array}{l}17025 \text { does not require a seal be used but does } \\
\text { require that appropriate safeguards be } \\
\text { employed. }\end{array}$ \\
\hline
\end{tabular}




\begin{tabular}{|c|c|c|}
\hline From the NUPIC Checklist & Relevant requirement(s) of ISO/IEC 17025 & Comments \\
\hline $\begin{array}{l}\text { Section IX - Calibration } \\
\text { Traceability } \\
9.1 \text { Verify that M\&TE, calibration } \\
\text { standards and reference materials are: } \\
\text { Traceable to national, international, } \\
\text { or intrinsic standards where } \\
\text { available. }\end{array}$ & $\begin{array}{l}\text { 5.6.1 General - All equipment used for tests and/or } \\
\text { calibrations, including equipment for subsidiary measurements } \\
\text { (e.g., for environmental conditions) having a significant effect on } \\
\text { the accuracy or validity of the result of the test, calibration or } \\
\text { sampling shall be calibrated before being put into service. The } \\
\text { laboratory shall have an established program and procedure for } \\
\text { the calibration of its equipment. } \\
\text { 5.6.2.1.1 For calibration laboratories, the program for } \\
\text { calibration of equipment shall be designed and operated so as to } \\
\text { ensure that calibrations and measurements made by the } \\
\text { laboratory are traceable to the International System of Units (SI) } \\
\text { (Système international d'unités). } \\
\text { A calibration laboratory establishes traceability of its own } \\
\text { measurement standards and measuring instruments to the SI by } \\
\text { means of an unbroken chain of calibrations or comparisons } \\
\text { linking them to relevant primary standards of the SI units of } \\
\text { measurement. The link to SI units may be achieved by reference } \\
\text { to national measurement standards. National measurement } \\
\text { standards may be primary standards, which are primary } \\
\text { realizations of the SI units or agreed representations of SI units } \\
\text { based on fundamental physical constants, or they may be } \\
\text { secondary standards which are standards calibrated by another } \\
\text { national metrology institute. When using external calibration } \\
\text { services, traceability of measurement shall be assured by the use } \\
\text { of calibration services from laboratories that can demonstrate } \\
\text { competence, measurement capability and traceability. The } \\
\text { calibration certificates issued by these laboratories shall contain } \\
\text { the measurement results, including the measurement uncertainty } \\
\text { and/or a statement of compliance with an identified metrological } \\
\text { specification (see also 5.10.4.2). }\end{array}$ & $\begin{array}{l}17025 \text { requires that all measurement results be } \\
\text { traceable to stated references per the accepted } \\
\text { definition of the term "traceability" as found } \\
\text { in the International Vocabulary of Basic and } \\
\text { General Terms in Metrology (VIM: 1993, } \\
\text { 6.10) and as adopted by NIST. } \\
\text { Furthermore, all recognized accreditation } \\
\text { bodies (signatories to the ILAC, APLAC, EA, } \\
\text { and/or NACLA MRA) have implementation } \\
\text { policies on traceability that follow the ILAC } \\
\text { Policy and Guidance documents. Verification } \\
\text { of traceability is fundamental to the } \\
\text { accreditation process. } \\
\text { 17025 specifies the acceptable path(s) of } \\
\text { traceability, requires that external calibration } \\
\text { labs be able to demonstrate competence, and } \\
\text { specifies what, at a minimum, must be } \\
\text { included in calibration certificates. } \\
\text { Furthermore, all accreditation bodies have } \\
\text { requirements to the effect that all calibration } \\
\text { services required to support a laboratory's } \\
\text { services, must come from national metrology } \\
\text { institutes or from accredited labs. }\end{array}$ \\
\hline
\end{tabular}




\begin{tabular}{|c|c|c|}
\hline From the NUPIC Checklist & Relevant requirement(s) of ISO/IEC 17025 & Comments \\
\hline $\begin{array}{l}\text { Where traceability to national, } \\
\text { international, or intrinsic standards of } \\
\text { measurement is not available, } \\
\text { traceability requirements may be } \\
\text { satisfied by: } \\
\text { a) participation in a suitable } \\
\text { program of inter-laboratory } \\
\text { comparisons or proficiency testing } \\
\text { b) internationally accepted } \\
\text { standards in the field concerned. } \\
\text { c) suitable reference materials } \\
\text { d) ratio or reciprocity type } \\
\text { measurements } \\
\text { e) mutual consent standards } \\
\text { agreed upon by all parties concerned }\end{array}$ & $\begin{array}{l}\text { 5.6.2.1.2 There are certain calibrations that currently cannot be } \\
\text { strictly made in SI units. In these cases calibration shall provide } \\
\text { confidence in measurements by establishing traceability to } \\
\text { appropriate measurement standards such as: } \\
\text { - } \quad \text { the use of certified reference materials provided by a } \\
\text { competent supplier to give a reliable physical or } \\
\text { chemical characterization of a material; } \\
\text { - } \quad \text { the use of specified methods and/or consensus standards } \\
\text { that are clearly described and agreed by all parties } \\
\text { concerned. } \\
\text { Participation in a suitable program of interlaboratory } \\
\text { comparisons is required where possible. }\end{array}$ & $\begin{array}{l}17025 \text { has provisions for situations where } \\
\text { traceability to the SI is not possible. In these } \\
\text { cases clients are to be notified up front and } \\
\text { service provider labs are required to correlate } \\
\text { their results with others making the same } \\
\text { measurements. }\end{array}$ \\
\hline
\end{tabular}




\begin{tabular}{|c|c|c|}
\hline From the NUPIC Checklist & Relevant requirement(s) of ISO/IEC 17025 & Comments \\
\hline $\begin{array}{l}\text { Section X - Subcontractor } \\
\text { Calibration } \\
10.1 \text { Verify the supplier assures that } \\
\text { sub-contractors providing calibration } \\
\text { services for their own M\&TE and } \\
\text { standards are capable of performing } \\
\text { the required services in accordance } \\
\text { with the documented program (ref. } \\
\text { Checklist Item 2.1). Assess } \\
\text { established controls for subcontractor } \\
\text { capability determined through } \\
\text { audits/surveys, source surveillance, } \\
\text { history, etc. } \\
\text { a) customer notification required } \\
\text { when calibration is subcontracted. } \\
\text { b) subcontractor capability } \\
\text { determined through audits/surveys, } \\
\text { source surveillance, history, etc. }\end{array}$ & $\begin{array}{l}\text { 4.6.1 The laboratory shall have a policy and procedure(s) for the } \\
\text { selection and purchasing of services and supplies it uses that } \\
\text { affect the quality of the tests and/or calibrations. Procedures shall } \\
\text { exist for the purchase, reception and storage of reagents and } \\
\text { laboratory consumable materials relevant for the tests and } \\
\text { calibrations. } \\
\text { 4.6.2 The laboratory shall ensure that purchased supplies and } \\
\text { reagents and consumable materials that affect the quality of tests } \\
\text { and/or calibrations are not used until they have been inspected or } \\
\text { otherwise verified as complying with standard specifications or } \\
\text { requirements defined in the methods for the tests and/or } \\
\text { calibrations concerned. These services and supplies used shall } \\
\text { comply with specified requirements. Records of actions taken to } \\
\text { check compliance shall be maintained. } \\
\text { 4.6.3 Purchasing documents for items affecting the quality of } \\
\text { laboratory output shall contain data describing the services and } \\
\text { supplies ordered. These purchasing documents shall be reviewed } \\
\text { and approved for technical content prior to release. } \\
\text { 4.6.4 The laboratory shall evaluate suppliers of critical } \\
\text { consumables, supplies and services which affect the quality of } \\
\text { testing and calibration, and shall maintain records of these } \\
\text { evaluations and list those approved. }\end{array}$ & $\begin{array}{l}\text { Clause } 10.1 \text { of the NUPIC checklist appears to } \\
\text { be a misinterpretation of the concept of } \\
\text { subcontracting as it applies to Z540-1 and } \\
17025 \text {. The requirements for subcontracting } \\
\text { apply when the laboratory intends to } \\
\text { subcontract the service it offers to it's } \\
\text { customers. When this happens there are clear } \\
\text { rules that must be followed in } 17025 \text {. } \\
\text { When a laboratory has its standards and } \\
\text { M\&TE calibrated by another laboratory, this } \\
\text { does not fall under subcontracting but under } \\
\text { purchasing of services. All, or at least most } \\
\text { laboratories purchase calibration services from } \\
\text { other labs to support the services they offer to } \\
\text { their customers. There is no need for the lab } \\
\text { to notify the customer when this happens. } \\
\text { There are well defined requirements for the } \\
\text { purchasing of services and/or supplies in } \\
\text { 17025. }\end{array}$ \\
\hline
\end{tabular}




\begin{tabular}{|c|c|c|}
\hline From the NUPIC Checklist & Relevant requirement(s) of ISO/IEC 17025 & Comments \\
\hline $\begin{array}{l}10.2 \text { Where calibration services for } \\
\text { customer M\&TE/standards are sub- } \\
\text { contracted, access controls for: } \\
\text { a) customer notification/approval } \\
\text { required } \\
\text { b) customer requirements imposed } \\
\text { on sub-contractor } \\
\text { b) subcontractor capability to meet } \\
\text { applicable requirements }\end{array}$ & $\begin{array}{l}\text { 4.5.1 When a laboratory subcontracts work whether because of } \\
\text { unforeseen reasons (e.g., workload, need for further expertise or } \\
\text { temporary incapacity) or on a continuing basis (e.g., through } \\
\text { permanent subcontracting, agency or franchising arrangements), } \\
\text { this work shall be placed with a competent subcontractor. A } \\
\text { competent subcontractor is one that, for example, complies with } \\
\text { this standard for the work in question. } \\
\text { 4.5.2 The laboratory shall advise the client of the arrangement } \\
\text { in writing and, when appropriate, gain the approval of the client, } \\
\text { preferably in writing. } \\
\text { 4.5.3 The laboratory is responsible to the client for the } \\
\text { subcontractor's work, except in the case where the client or a } \\
\text { regulatory authority specifies which subcontractor is to be used. } \\
\text { 4.5.4 The laboratory shall maintain a register of all } \\
\text { subcontractors that it uses for tests and/or calibrations and a } \\
\text { record of the evidence of compliance with this standard for the } \\
\text { work in question. }\end{array}$ & $\begin{array}{l}17025 \text { requires that subcontracted service } \\
\text { providers be competent, that the customer be } \\
\text { notified in writing, and that the subcontracting } \\
\text { laboratory maintains responsibility for the } \\
\text { services provided to its customers. } 17025 \text { also } \\
\text { requires that a register of qualified } \\
\text { subcontractors be maintained which includes } \\
\text { evidence of compliance to the standard. }\end{array}$ \\
\hline $\begin{array}{l}\text { Section XI - Storage and Handling } \\
11.1 \text { Verify M\&TE and Standards } \\
\text { are handled, stored, and transported } \\
\text { in accordance with established } \\
\text { laboratory procedures to avoid } \\
\text { deterioration or damage, which could } \\
\text { affect the calibration of the } \\
\text { equipment. }\end{array}$ & $\begin{array}{l}\text { 5.5.6 The laboratory shall have procedures for safe handling, } \\
\text { transport, storage, use and planned maintenance of measuring } \\
\text { equipment to ensure proper functioning and in order to prevent } \\
\text { contamination or deterioration. }\end{array}$ & $\begin{array}{l}17025 \text { also requires that, when the subject } \\
\text { standard or M\&TE becomes a "calibration } \\
\text { item", the requirements of section 5.8: } \\
\text { "Handling of test and calibration items" } \\
\text { apply. }\end{array}$ \\
\hline
\end{tabular}




\begin{tabular}{|c|c|c|}
\hline From the NUPIC Checklist & Relevant requirement(s) of ISO/IEC 17025 & Comments \\
\hline $\begin{array}{l}\text { Section XII - Out of } \\
\text { Tolerance/Corrective Action } \\
12.1 \text { Verify the supplier's system } \\
\text { provides for customer notification } \\
\text { when Laboratory's M\&TE/standards } \\
\text { and/or customer's M\&TE/standards } \\
\text { are found to be significantly out-of- } \\
\text { tolerance. Evaluate the adequacy of } \\
\text { the definition of significant and the } \\
\text { associated corrective action } \\
\text { measures. }\end{array}$ & $\begin{array}{l}\text { 4.9.1 The laboratory shall have a policy and procedures that } \\
\text { shall be implemented when any aspect of its testing and/or } \\
\text { calibration work, or the results of this work, do not conform to } \\
\text { its own procedures or the agreed requirements of the client. The } \\
\text { policy and procedures shall ensure that: } \\
\text { a) } \\
\text { the responsibilities and authorities for the management } \\
\text { of nonconforming work are designated and actions } \\
\text { (including halting of work and withholding of test } \\
\text { reports and calibration certificates, as necessary) are } \\
\text { defined and taken when nonconforming work is } \\
\text { identified; } \\
\text { an evaluation of the significance of the nonconforming } \\
\text { work is made; } \\
\text { corrective actions are taken immediately, together with } \\
\text { any decision about the acceptability of the } \\
\text { nonconforming work; } \\
\text { where necessary, the client is notified and work is } \\
\text { recalled; } \\
\text { the responsibility for authorizing the resumption of work } \\
\text { e) }\end{array}$ & $\begin{array}{l}17025 \text { contains requirements for notification } \\
\text { of the customer when there is evidence of } \\
\text { non-conforming work. Out-of-tolerance } \\
\text { conditions are considered non-conforming } \\
\text { work. } 17025 \text { also identifies the aspect of } \\
\text { recalling non-conforming work from the } \\
\text { customer for recalibration when necessary. }\end{array}$ \\
\hline
\end{tabular}




\begin{tabular}{|c|c|c|}
\hline From the NUPIC Checklist & Relevant requirement(s) of ISO/IEC 17025 & Comments \\
\hline $\begin{array}{l}\text { (continued) } \\
\text { Also, verify the system provides for } \\
\text { the prevention of inaccuracy by } \\
\text { detection of deficiencies and timely, } \\
\text { positive action for their correction. }\end{array}$ & $\begin{array}{l}\text { 4.10 Corrective action } \\
\text { 4.10.1 General - The laboratory shall establish a policy and } \\
\text { procedure and shall designate appropriate authorities for } \\
\text { implementing corrective action when nonconforming work or } \\
\text { departures from the policies and procedures in the quality system } \\
\text { or technical operations have been identified. } \\
4.10 .2 \text { Cause analysis - The procedure for corrective action } \\
\text { shall start with an investigation to determine the root cause(s) of } \\
\text { the problem. } \\
4.10 .3 \text { Selection and implementation of corrective actions - } \\
\text { Where corrective action is needed, the laboratory shall identify } \\
\text { potential corrective actions. It shall select and implement the } \\
\text { action(s) most likely to eliminate the problem and to prevent } \\
\text { recurrence. } \\
4.10 .4 \text { Monitoring of corrective actions - The laboratory shall } \\
\text { monitor the results to ensure that the corrective actions taken } \\
\text { have been effective. } \\
4.10 .5 \text { Additional audits - Where the identification of } \\
\text { nonconformances or departures casts doubts on the laboratory's } \\
\text { compliance with its own policies and procedures, or on its } \\
\text { compliance with this handbook, the laboratory shall ensure that } \\
\text { the appropriate areas of activity are audited in accordance with } \\
4.13 \text { as soon as possible. }\end{array}$ & $\begin{array}{l}17025 \text { also requires that corrective actions be } \\
\text { monitored and that when necessary, additional } \\
\text { audits be conducted to ensure the effectiveness } \\
\text { of corrective actions taken. }\end{array}$ \\
\hline
\end{tabular}




\begin{tabular}{||l||l||l||}
\hline \hline From the NUPIC Checklist & Relevant requirement(s) of ISO/IEC 17025 & Comments \\
\hline \hline (continued) & $\begin{array}{l}411 \text { Preventive action } \\
\text { 4.11.1 Needed improvements and potential sources of } \\
\text { nonconformances, either technical or concerning the quality } \\
\text { system, shall be identified. If preventive action is required, } \\
\text { action plans shall be developed, implemented and monitored to } \\
\text { reduce the likelihood of the occurrence of such nonconformances } \\
\text { and to take advantage of the opportunities for improvement. }\end{array}$ & $\begin{array}{l}17025 \text { implements an additional requirement } \\
\text { for the laboratory to identify potential sources } \\
\text { of non-conformances and to establish } \\
\text { preventive action procedures when necessary. }\end{array}$ \\
& $\begin{array}{l}4.11 .2 \text { Procedures for preventive actions shall include the } \\
\text { initiation of such actions and application of controls to ensure } \\
\text { that they are effective. }\end{array}$ & \\
\hline
\end{tabular}




\begin{tabular}{|c|c|c|}
\hline From the NUPIC Checklist & Relevant requirement(s) of ISO/IEC 17025 & Comments \\
\hline $\begin{array}{l}\text { Section XIII - Calibration System } \\
\text { Adequacy } \\
\text { 13.1 Verify the supplier has } \\
\text { established and maintains documented } \\
\text { procedures to: } \\
\text { a) Evaluate the adequacy of the } \\
\text { calibration system through internal } \\
\text { audits or equivalent oversight to } \\
\text { verify compliance with established } \\
\text { requirements. }\end{array}$ & $\begin{array}{l}\text { 4.13.1 The laboratory shall periodically, and in accordance with } \\
\text { a predetermined schedule and procedure, conduct internal audits } \\
\text { of its activities to verify that its operations continue to comply } \\
\text { with the requirements of the quality system and this standard. } \\
\text { The internal audit program shall address all elements of the } \\
\text { quality system, including the testing and/or calibration activities. } \\
\text { It is the responsibility of the quality manager to plan and } \\
\text { organize audits as required by the schedule and requested by } \\
\text { management. Such audits shall be carried out by trained and } \\
\text { qualified personnel who are, wherever resources permit, } \\
\text { independent of the activity to be audited. NOTE: The cycle for } \\
\text { internal auditing should normally be completed in one year. } \\
4.13 .2 \text { When audit findings cast doubt on the effectiveness of } \\
\text { the operations or on the correctness or validity of the } \\
\text { laboratory's test or calibration results, the laboratory shall take } \\
\text { timely corrective action, and shall notify clients in writing if } \\
\text { investigations show that the laboratory results may have been } \\
\text { affected. } \\
4.13 .3 \text { The area of activity audited, the audit findings and } \\
\text { corrective actions that arise from them shall be recorded. } \\
4.13 .4 \text { Follow-up audit activities shall verify and record the } \\
\text { implementation and effectiveness of the corrective action taken. } \\
4.14 .1 \text { In accordance with a predetermined schedule and } \\
\text { procedure, the laboratory's executive management shall } \\
\text { periodically conduct a review of the laboratory's quality system } \\
\text { and testing and/or calibration activities to ensure their continuing } \\
\text { suitability and effectiveness, and to introduce necessary changes } \\
\text { or improvements. }\end{array}$ & $\begin{array}{l}17025 \text { contains detailed requirements for } \\
\text { internal audits and management reviews. } \\
17025 \text { also requires that auditors be properly } \\
\text { trained to conduct audits and independent of } \\
\text { the area being audited, where possible. }\end{array}$ \\
\hline
\end{tabular}




\begin{tabular}{|c|c|c|}
\hline From the NUPIC Checklist & Relevant requirement(s) of ISO/IEC 17025 & Comments \\
\hline $\begin{array}{l}\text { b) In addition to internal audits, are } \\
\text { internal checks implemented?: } \\
\text { 1. statistical techniques } \\
\text { 2. proficiency testing/inter- } \\
\text { laboratory comparisons } \\
\text { 3. use of certified reference } \\
\text { materials } \\
\text { 4. use of alternate methods for } \\
\text { replicating measurements }\end{array}$ & $\begin{array}{l}\text { Assuring the quality of test and calibration results } \\
\text { The laboratory shall have quality control procedures for } \\
\text { monitoring the validity of tests and calibrations undertaken. The } \\
\text { resulting data shall be recorded in such a way that trends are } \\
\text { detectable and, where practicable, statistical techniques shall be } \\
\text { applied to the reviewing of the results. This monitoring shall be } \\
\text { planned and reviewed and may include, but not be limited to, the } \\
\text { following: } \\
\text { a) } \\
\text { integular use of certified reference materials and/or } \\
\text { materials; } \\
\text { participation in interlaboratory comparison or } \\
\text { proficiency-testing programs; } \\
\text { b) replicate tests or calibrations using the same or different } \\
\text { methods; } \\
\text { c) retesting or recalibration of retained items; } \\
\text { d) correlation of results for different characteristics of an } \\
\text { item. } \\
\text { e) } \\
\text { NOTE The selected methods should be appropriate for the type } \\
\text { and volume of the work undertaken. }\end{array}$ & $\begin{array}{l}17025 \text { includes a new section specifically on } \\
\text { "Assuring the quality of test and calibration } \\
\text { results." }\end{array}$ \\
\hline
\end{tabular}




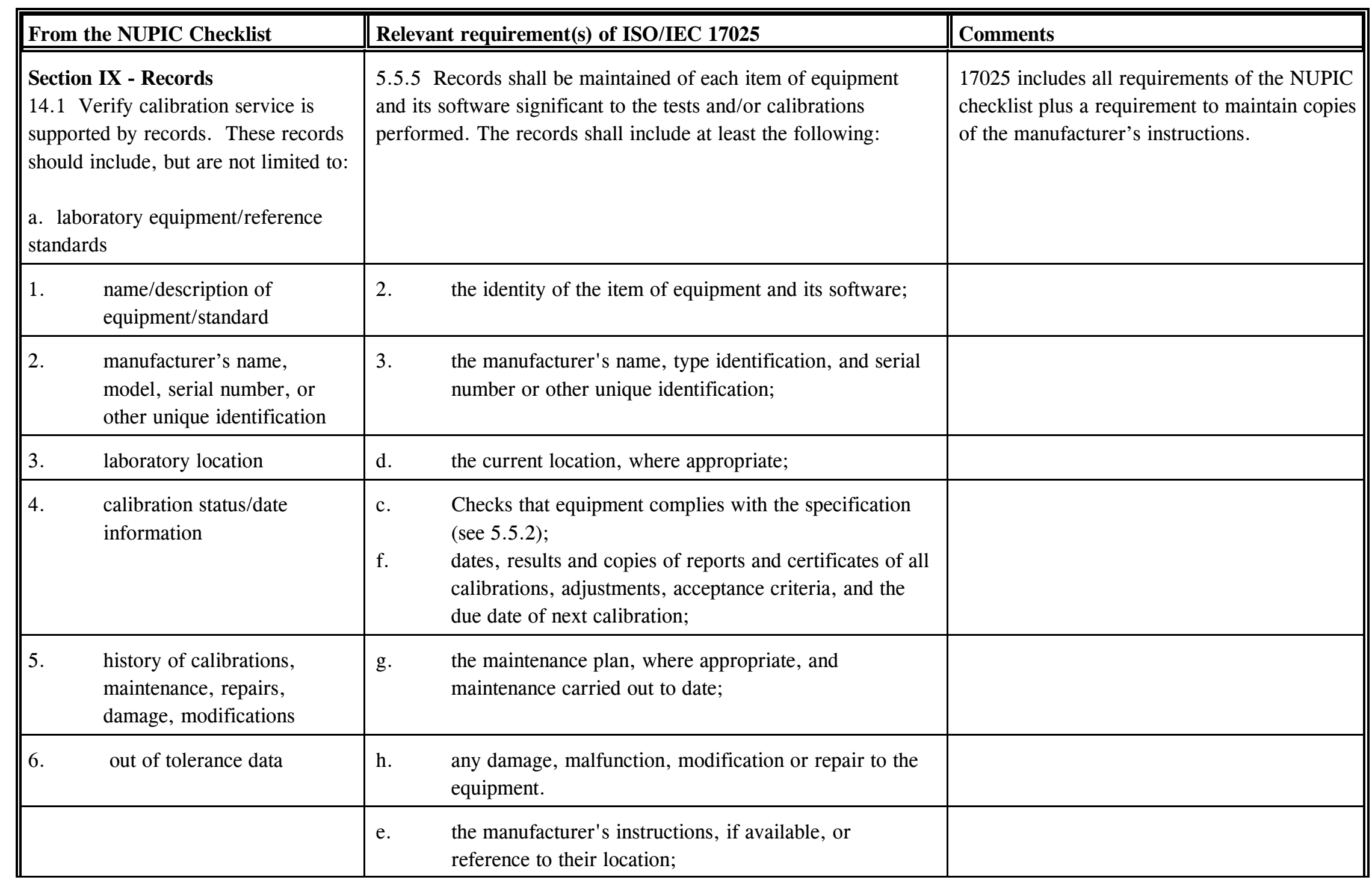




\begin{tabular}{|c|c|c|}
\hline From the NUPIC Checklist & Relevant requirement(s) of ISO/IEC 17025 & Comments \\
\hline $\begin{array}{l}\text { (14.1) b. } \text { calibration personnel } \\
\text { 1. } \quad \text { training courses } \\
\text { 2. } \quad \text { prior education/experience } \\
\text { 3. } \quad \text { qualifications/certifications }\end{array}$ & $\begin{array}{l}\text { 5.2.5 The management shall authorize specific personnel to } \\
\text { perform particular types of sampling, test and/or calibration, to } \\
\text { issue test reports and calibration certificates, to give opinions and } \\
\text { interpretations and to operate particular types of equipment. The } \\
\text { laboratory shall maintain records of the relevant authorization(s), } \\
\text { competence, educational and professional qualifications, training, } \\
\text { skills and experience of all technical personnel, including } \\
\text { contracted personnel. This information shall be readily available } \\
\text { and shall include the date on which authorization and/or } \\
\text { competence is confirmed. }\end{array}$ & $\begin{array}{l}17025 \text { also requires that records of the specific } \\
\text { authorizations for certain functions be kept. }\end{array}$ \\
\hline c. calibration certificate/report & $\begin{array}{l}\text { 5.10.2 Test reports and calibration certificates } \\
\text { Each test report or calibration certificate shall include at least the } \\
\text { following information, unless the laboratory has valid reasons for } \\
\text { not doing so: }\end{array}$ & $\begin{array}{l}17025 \text { requires that suppliers of calibration } \\
\text { services meet the requirements of the } \\
\text { standard. The standard requires certain } \\
\text { information be included in calibration } \\
\text { certificates/reports. Section } 5.10 \text { applies. }\end{array}$ \\
\hline $\begin{array}{l}\text { 1. title, unique identification } \\
\text { number }\end{array}$ & $\begin{array}{l}\text { a) a title (e.g., "Test Report" or "Calibration Certificate"); } \\
\text { unique identification of the test report or calibration } \\
\text { certificate (such as the serial number), and on each page } \\
\text { an identification in order to ensure that the page is } \\
\text { recognized as a part of the test report or calibration } \\
\text { certificate, and a clear identification of the end of the } \\
\text { test report or calibration certificate; }\end{array}$ & $\begin{array}{l}17025 \text { also requires page identification and } \\
\text { end of report identification. }\end{array}$ \\
\hline $\begin{array}{l}\text { 2. calibration laboratory } \\
\text { location }\end{array}$ & $\begin{array}{l}\text { b) the name and address of the laboratory, and the location } \\
\text { where the tests and/or calibrations were carried out, if } \\
\text { different from the address of the laboratory; }\end{array}$ & $\begin{array}{l}17025 \text { requires that the lab and the location } \\
\text { where the calibration was conducted be } \\
\text { identified, if different. }\end{array}$ \\
\hline $\begin{array}{l}\text { 3. } \\
\text { name/omer } \\
\text { number }\end{array}$ & the name and address of the client; & $\begin{array}{l}17025 \text { does not require the purchase order } \\
\text { number to appear on the certificate. It has } \\
\text { little relevance to the calibration performed. }\end{array}$ \\
\hline $\begin{array}{l}\text { 4. unique identification of } \\
\text { calibrated equipment }\end{array}$ & $\begin{array}{l}\text { a description of, the condition of, and unambiguous } \\
\text { identification of the item(s) tested or calibrated; }\end{array}$ & $\begin{array}{l}17025 \text { also requires that a description of and } \\
\text { the condition of the calibrated equipment be } \\
\text { provided. }\end{array}$ \\
\hline
\end{tabular}




\begin{tabular}{|c|c|c|}
\hline From the NUPIC Checklist & Relevant requirement(s) of ISO/IEC 17025 & Comments \\
\hline 5. calibration date & $\begin{array}{l}\text { g) the date of receipt of the test or calibration item(s) } \\
\text { where this is critical to the validity and application of } \\
\text { the results, and the date(s) of performance of the test or } \\
\text { calibration; }\end{array}$ & $\begin{array}{l}17025 \text { also requires the date of receipt where } \\
\text { this information is critical. }\end{array}$ \\
\hline 6. calibration procedure used & e) identification of the method used; & $\begin{array}{l}17025 \text { requires that the method of calibration } \\
\text { be identified as opposed to simply naming the } \\
\text { procedure. }\end{array}$ \\
\hline $\begin{array}{ll}\text { 7. } & \text { laboratory } \\
& \text { equipment/standards used }\end{array}$ & & $\begin{array}{l}\text { Not required by } 17025 \text { to be included in the } \\
\text { report. } 17025 \text { does require that the } \\
\text { information be recorded in the laboratory's } \\
\text { records. }\end{array}$ \\
\hline $\begin{array}{l}\text { 8. deviations or out-of- } \\
\text { tolerance conditions notation }\end{array}$ & $\begin{array}{l}\text { i) the test or calibration results with, where appropriate, } \\
\text { the units of measurement; and } \\
\text { 5.10.4.2 The calibration certificate shall relate only to quantities } \\
\text { and the results of functional tests. If a statement of compliance } \\
\text { with a specification is made, this shall identify which clauses of } \\
\text { the specification are met or not met. } \\
\text { When a statement of compliance with a specification is made } \\
\text { omitting the measurement results and associated uncertainties, } \\
\text { the laboratory shall record those results and maintain them for } \\
\text { possible future reference. } \\
\text { When statements of compliance are made, the uncertainty of } \\
\text { measurement shall be taken into account. }\end{array}$ & $\begin{array}{l}17025 \text { requires that results be reported, good } \\
\text { or bad, or that a statement of compliance (or } \\
\text { non-compliance) to a metrological } \\
\text { specification be made. }\end{array}$ \\
\hline
\end{tabular}




\begin{tabular}{|c|c|c|}
\hline From the NUPIC Checklist & \multirow{2}{*}{$\begin{array}{l}\text { Relevant requirement(s) of ISO/IEC } \mathbf{1 7 0 2 5} \\
\text { 5.10.4.1 In addition to the requirements listed in 5.10.2, } \\
\text { calibration certificates shall include the following, where } \\
\text { necessary for the interpretation of calibration results: }\end{array}$} & \multirow{2}{*}{$\begin{array}{l}\text { Comments } \\
17025 \text { requires that an uncertainty of the } \\
\text { measurement result be reported and that, } \\
\text { where a statement of compliance is made, } \\
\text { uncertainty must be accounted for. }\end{array}$} \\
\hline $\begin{array}{l}\text { collective uncertainty } \\
\text { statement }\end{array}$ & & \\
\hline $\begin{array}{l}\text { 10. } \\
\text { traceability to national } \\
\text { standards statement }\end{array}$ & $\begin{array}{l}\text { c) evidence that the measurements are traceable (see note } 2 \\
\text { in 5.6.2.1.1). }\end{array}$ & $\begin{array}{l}17025 \text { requires that the stated reference, } \\
\text { usually national standards, be identified. }\end{array}$ \\
\hline $\begin{array}{l}\text { 11. signature/title of laboratory } \\
\text { approval person }\end{array}$ & $\begin{array}{ll}5.10 .2 & \\
\mathrm{j}) & \text { the name(s), function(s) and signature(s) or equivalent } \\
\text { identification of person(s) authorizing the test report or } \\
\text { calibration certificate; }\end{array}$ & $\begin{array}{l}17025 \text { requires the signature of the person } \\
\text { assuming responsibility for the reported } \\
\text { results. Laboratory accreditation defines this } \\
\text { as the Approved Signatory. }\end{array}$ \\
\hline \multirow[t]{2}{*}{$\begin{array}{l}\text { 12. calibration results data (as- } \\
\text { found \& as-left) }\end{array}$} & $\begin{array}{l}\text { 5.10.4.3 When an instrument for calibration has been adjusted } \\
\text { or repaired, the calibration results before and after adjustment or } \\
\text { repair, if available, shall be reported. }\end{array}$ & $\begin{array}{l}17025 \text { requires reporting of as-found and as- } \\
\text { left data only if the calibration item has been } \\
\text { adjusted/repaired but records must be } \\
\text { maintained of the data at all times. }\end{array}$ \\
\hline & $\begin{array}{l}\text { Additional reporting requirements of } 17025 \text { are as follows: } \\
\text { 5.10.2 } \\
\text { h) reference to the sampling plan and procedures used by } \\
\text { the laboratory or other bodies where these are relevant } \\
\text { to the validity or application of the results; } \\
\text { where relevant, a statement to the effect that the results } \\
\text { k) relate only to the items tested or calibrated. } \\
\text { 5.10.4.1 } \\
\text { a) the conditions (e.g., environmental) under which the } \\
\text { calibrations were made that have an influence on the } \\
\text { measurement results; }\end{array}$ & No equivalent NUPIC requirement. \\
\hline
\end{tabular}




\begin{tabular}{|c|c|c|}
\hline From the NUPIC Checklist & Relevant requirement(s) of ISO/IEC 17025 & Comments \\
\hline & $\begin{array}{l}\text { 5.10.4.4 A calibration certificate (or calibration label) shall not } \\
\text { contain any recommendation on the calibration interval except } \\
\text { where this has been agreed with the client. This requirement may } \\
\text { be superseded by legal regulations. } \\
\text { 5.10.5 Opinions and interpretations } \\
\text { When opinions and interpretations are included, the laboratory } \\
\text { shall document the basis upon which the opinions and } \\
\text { interpretations have been made. Opinions and interpretations } \\
\text { shall be clearly marked as such in a test report. }\end{array}$ & \\
\hline $\begin{array}{l}\text { Note: verify that quality program } \\
\text { document specifies record retention } \\
\text { period; and determine } \\
\text { implementation effectiveness. }\end{array}$ & $\begin{array}{l}\text { 4.12.1.2 All records shall be legible and shall be stored and } \\
\text { retained in such a way that they are readily retrievable in } \\
\text { facilities that provide a suitable environment to prevent damage } \\
\text { or deterioration and to prevent loss. Retention times of records } \\
\text { shall be established. }\end{array}$ & $\begin{array}{l}17025 \text { requires that the laboratory define its } \\
\text { record retention requirements based on the } \\
\text { needs of its customers and the relevant } \\
\text { regulatory requirements. }\end{array}$ \\
\hline
\end{tabular}




\section{Appendix A}

ISO/IEC 17025:1999 Table of Contents

Foreword

Introduction

1. Scope

2. Normative references

3. Terms and definitions

4. Management requirements

4.1 Organization

4.2 Quality system

4.3 Document control

4.4 Review of requests, tenders and contracts

4.5 Subcontracting of tests and calibrations

4.6 Purchasing services and supplies

4.7 Service to the client

4.8 Complaints

4.9 Control of nonconforming testing and/or calibration work

4.10 Corrective action
4.11 Preventive action

4.12 Control of records

4.13 Internal audits

4.14 Management reviews

5 Technical requirements

5.1 General

5.2 Personnel

5.3 Accommodation and environmental conditions

5.4 Test and calibration methods and method validation

5.5 Equipment

5.6 Measurement traceability

5.7 Sampling

5.8 Handling of test and calibration items

5.9 Assuring the quality of test and calibration results

5.10 Reporting the results

Annex A (informative) Nominal cross-references to ISO 9001:1994 and ISO 9002:1994

Annex B (informative) Guidelines for establishing applications for specific fields

Bibliography 